\title{
A Model of Sustainable Leadership for Leaders in Double First-Class Universities in China
}

\author{
Xiaoyao Yue ${ }^{1}$, Yongjun Feng ${ }^{2} \&$ Yan $\mathrm{Ye}^{3}$ \\ ${ }^{1}$ Research institute of higher education, Yunnan University, Yunnan province, China \\ ${ }^{2}$ School of education, Shaanxi Normal University, Shaanxi province, China \\ ${ }^{3}$ Graduate school of education, Stamford International University, Bangkok, Thailand \\ Correspondence: Yongjun Feng, School of education, Shaanxi Normal University, Shaanxi province, China.
}

Received: December 10, 2020

Accepted: January 16, 2021

Online Published: January 19, 2021

doi:10.5430/ijhe.v10n3p187

URL: https://doi.org/10.5430/ijhe.v10n3p187

\begin{abstract}
Owing to the context in which higher education institutions function, models of sustainable leadership have not been applied to this area. Yet China is now the world's second largest economic entity, and higher education plays an integral role in the country's development. In August 2015, China's State Council published the Overall Plan for Coordinately Advancing the Construction of World First-class Universities and First-class Disciplines. This paper reviews and analyzes research and theories related to effective leadership and sustainable leadership, which is applied in education and higher education institutions, especially in China. The current challenges of double first-class universities in China will be determined. Under this situation, according to two eras of literatures on effective leadership and sustainable leadership in higher education, the author will develop a model of sustainable leadership for leaders in double first-class universities in China.
\end{abstract}

Keywords: sustainable leadership, higher education leadership, Chinese universities, double first-class universities

\section{Introduction}

Sustainability can be defined in various ways. It is currently popular in the contexts of government, business, and non-profit organizations (Crews, 2010). In Lambert's (2011) research, there is a nexus between sustainability and environment, ecology, and reserve energy. There is an enormous body of literature on sustainable leadership, which investigates leadership that aims to preserve the environment of the organization. Scholars define that leaders develop sustainability in various ways, such as: commitment to deep learning in the campus; continuing to reinforce and provide knowledge for everyone in the organization; and providing support to keep them working (Lambert, 2011).

Sustainable leadership, as an emerging notion, has inquired by few scholars, however, the existing models are not completely accurate for higher education (HE). Sustainable leadership in this context is at an early stage, and related literature has only emerged since 2003. Most prior research on sustainable leadership referred only to K-12 education, while hardly considered to apply it in HE area (Lambert, 2011, 2012). Educational leaders can insist on their vision through attempting to confirm the progress and situation are consensus, mainly when they leaved the universities (Clarke and Stevens, 2009). Sustainable leadership requires distributing responsibility, so as to avoid exhausting the resources of human and finance, as well as paying attention to and preventing the destruction of the surrounding educational and community environment. Universities are not allowed to lure students with unreasonable perks such as excessive scholarships or placement promises.

Cook (2014) continually argues that sustainable leadership has sets of activists to involve people, and creates an educational environment with community diversity, enabling cross-pollination of great views and compelling experiences in organizations of collective learning and development. This viewpoint suggests the importance of enhancing a university climate of collaboration through shared values, visions, and beliefs. This climate shows that the basis of sustainable leadership, and could be learned and communicated. Moreover, the focus of sustainability extends beyond life and death matters, and is not merely a time-related thing. Sustainability is also a topic related to the "space", not merely continuation. It requires the development of a special issue which does not need the compromise of other development at present and future (Hargreaves and Fink, 2003b). Hargreaves (2007) defines sustainable leadership as preserving and developing everything that spreads and continues deeply, without being damaged, and positively influencing others, both today and in the future. 
As a constituent element of China's nation-building project, HE is a pivotal part of the country's political strategy of creating national strength through science and education. One approach to achieving this objective is to develop HE of international eminence (Yang and Welch, 2012). China is now the world's second largest economic entity, and it's HE plays an integral role in national development. In August 2015, China's State Council published the Overall Plan for Coordinately Advancing the Construction of World First-class Universities and First-class Disciplines - the newest policy for crucial universities. Zhao et al. (2019) investigated the extent of research on top world universities and double first-class universities by searching for articles indexed in China National Knowledge Infrastructure (CNKI). They found 6,944 articles, whose publication distribution over time is depicted in Figure 1. Academics have paid more attention to researching top universities since the policy was published in 2015. There is limited of researches of sustainable leadership for university development and no research for China. This article will explore a model of sustainable leadership that could foster double first-class university development.

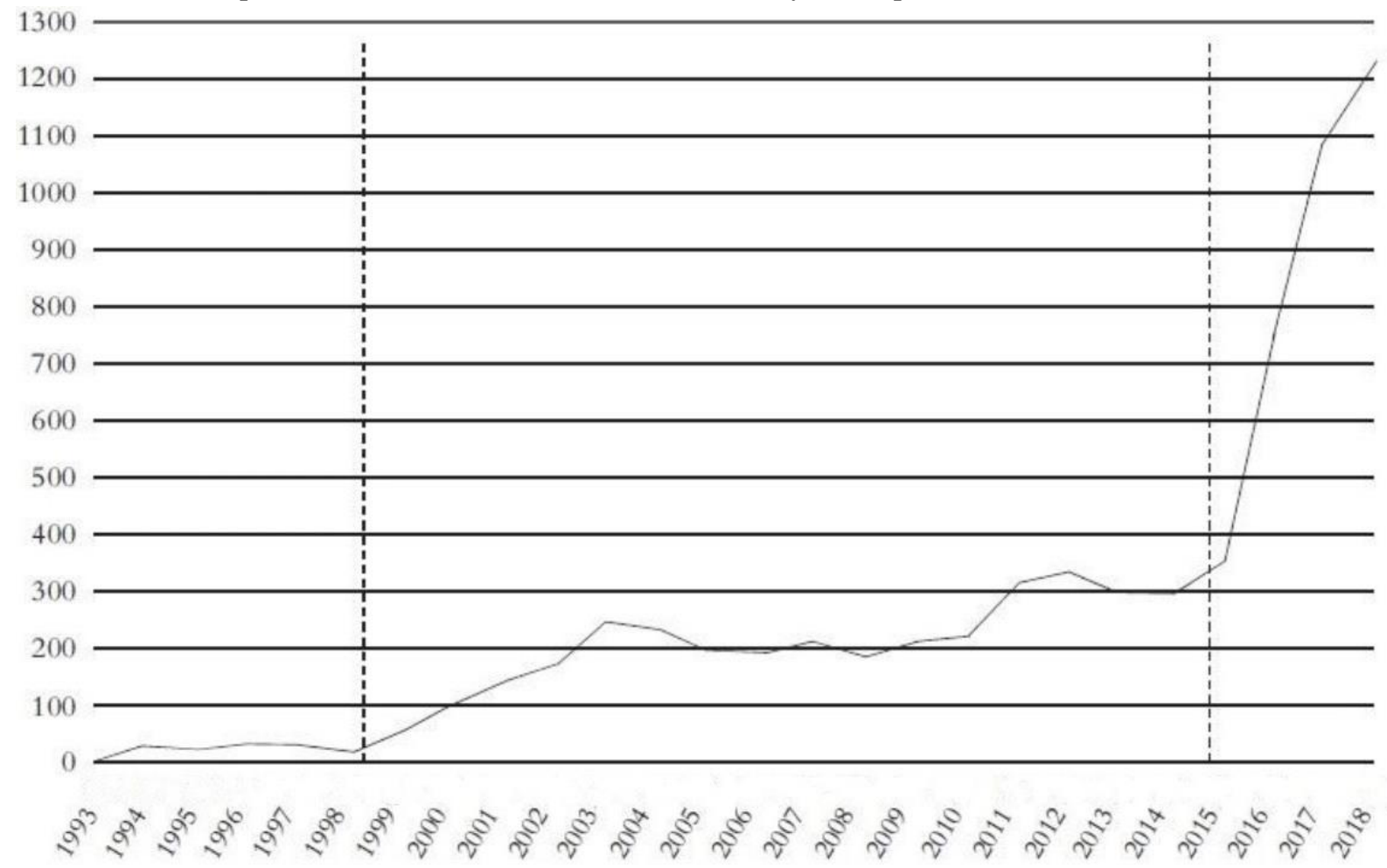

Figure 1. Changes in the number of studies published on the theme of "World-Class Universities" (Zhao et al., 2019)

\section{Method and Materials}

The authors adopted the literature review method for this paper. This work reviewed and analyzed mainstream research on effective leadership and sustainable leadership in HE. Moreover, the authors compared the current models and theories of effective leadership and sustainable leadership, integrated the key elements and components, especially inspire by the studies of Lambert $(2011,2012)$ and Black (2015). Thus, this study's aim is to propose a framework of sustainable leadership for HE, particularly for double first-class universities in China.

\subsection{Effective Leadership in the HE Sector}

Since the 1980s, the leadership of higher education institutions (HEIs) has received growing attention, with student numbers rising, transformation in the funding for students, increased marketization and student selection, and continuing globalization in this domain. New ways to lead in HEIs are being identified as universities experience the double challenges of surviving in both natively and globally competitive world that presents opportunities to create and develop sustainable leadership. While facing similar challenges to all businesses, universities call for giving their role in developing new knowledge and the themes of current knowledge (Jones et al., 2012). Ameijde et al. (2009) conducted a qualitative study of distributed leadership in HE, focusing on a situation of continuous pressures for institutional change. Their findings yielded suggestions on how to improve distributed leadership in university. Jones et al. (2012) also studied educational leadership in HE, but only examined a distributed leadership program in 
universities. In this trend of change, HEIs have to deem how to develop the organization and what might be effective leadership for adapting to these new environments.

Black (2015) analyzed the leadership models in HEIs to develop a comparison of typical frameworks using a general model of leadership (see Table 1). This draws on the work of Black et al. (2006), who proposed five practices of exemplary leadership: model the way, inspire a shared vision, challenge the process, enable others to act, and encourage the heart. This leadership model supports the simple approaches required to build the significant and sustainable change that eventually standardizes best practices, enables results, and cuts down costs through inter-organizational partnerships (Kouzes and Posner, 2011).

Regarding the theory of transformative leadership in HE, Astin and Astin (2000) pointed out the principles of university leadership in their book. In 2007, Bryman conducted a literature review of effective university department leadership. He reviewed publications from the USA, UK, and Australia, and summarized the notions of HE leadership. In McCaffery's (2019) recently published Higher Education Manager's Handbook, he proposes that effective management and leadership in HE is based on four "knows":

- Know the environment

- Know the university

- Know the department

- Know yourself

Bolden et al. (2013) defined the dimensions of leadership in HE by interviewing 152 leaders from 12 UK universities. In Rethinking the "L" Word in Higher Education, Kezar (2008) proposed the complexity and chaos theory of leadership in HE: with today's world full of disorder and uncertainties, universities play a critical role in providing new leaders that have to transform and change to meet society's needs. Spendlove (2007) investigated presidents and leaders of universities to identify the competencies (attitudes, knowledge, and behavior) that are necessary for effective leadership in HEIs.

The author also sought to diverse a practical leadership framework for HE by reviewing and critiquing related models and theories (see Table 1). Effective leadership in HEIs has four dimensions. Lead self refers to illuminating one's values for the whole organization. It is essential for the leader to build their credibility. For university leaders, the key to leadership is modeling the desired behaviors - setting an example that others will emulate. Knowing yourself is crucial; educational leaders have to know who they are, where they are, and what they want to do. Self-awareness is a fundamental capacity. Knowledge of the university and its circumstances will enable presidents to develop their institutions. Lead the system entails inspiring a clearly shared vision for the university. Collect small success could help all the organizational members with building confidence. Leaders need to create a learning community and should not neglect evaluation of mission and performance. Innovation is the core value of university development. Lead people entails fostering staff collaboration, enabling everyone to develop leadership competencies, listening to and understanding others' views and situations, and, in particular, treating staff authentically. Finally, Lead on the environment refers to the responsibility of HE managers to ensure sustainable use of resources, seek outside opportunities to strengthen institutional abilities, create and develop a network with other universities and organizations, personnel, and work to sustain academic stature. Weenen (2000) mentioned that sustainable development is one of the most challenging issues of the $21^{\text {st }}$ century. Sustainable leaders integrate sustainability into their university vision and develop their strategic plans to achieve it. 
Table 1. Comparison of typical higher education leadership frameworks, based on a general model_of leadership

\begin{tabular}{|c|c|c|c|c|c|c|}
\hline $\begin{array}{l}\text { Five Practices of } \\
\text { Exemplary } \\
\text { Leadership } \\
\text { (Kouzes and } \\
\text { Posner, 2006) }\end{array}$ & $\begin{array}{l}\text { Transformative } \\
\text { Leadership in } \\
\text { HE } \\
\text { (Astin and } \\
\text { Astin, } \\
\text { 2000) }\end{array}$ & $\begin{array}{l}\text { Effective } \\
\text { University } \\
\text { Department } \\
\text { Leadership } \\
\text { (Bryman, 2007) }\end{array}$ & $\begin{array}{l}\text { Effective } \\
\text { management } \\
\text { and leadership } \\
\text { in higher } \\
\text { education } \\
\text { (McCaffery, } \\
\text { 2019) }\end{array}$ & $\begin{array}{l}\text { Dimensions of } \\
\text { leadership in } \mathrm{HE} \\
\text { (Bolden et al., } \\
\text { 2013) }\end{array}$ & $\begin{array}{l}\text { Complexity and } \\
\text { chaos theory of } \\
\text { leadership in HE } \\
\text { (Kezar, 2008) }\end{array}$ & $\begin{array}{l}\text { Competencies for } \\
\text { effective leadership } \\
\text { in higher education } \\
\text { (Spendlove, 2007) }\end{array}$ \\
\hline $\begin{array}{l}\text { Model the way: } \\
\text { - Find your voice } \\
\text { by illuminating } \\
\text { your values } \\
\text { - Set the example by } \\
\text { allying actions with } \\
\text { common purpose }\end{array}$ & $\begin{array}{l}\text { - Create a } \\
\text { supportive and } \\
\text { learning } \\
\text { environment } \\
\text { - Provide } \\
\text { sustainability for } \\
\text { the next } \\
\text { generation }\end{array}$ & $\begin{array}{l}\text { - Provide a } \\
\text { clear vision } \\
\text { and strategic } \\
\text { leadership } \\
\text { - Prepare } \\
\text { arrangements } \\
\text { to facilitate } \\
\text { pursuing the } \\
\text { chosen } \\
\text { direction }\end{array}$ & $\begin{array}{l}\text { Know your } \\
\text { environmen } \\
\text { t: } \\
\text { • Equality \& } \\
\text { diversity } \\
\text { - Values \& vision } \\
\text { - Funding } \\
\text { - HR } \\
\text { - Marketing } \\
\text { - Competition }\end{array}$ & $\begin{array}{l}\text { Individual: } \\
\text { - Personal qualities } \\
\text { - Experience } \\
\text { - Role }\end{array}$ & $\begin{array}{l}\text { - Initiate } \\
\text { expertise } \\
\text { - Colleges and } \\
\text { universities } \\
\text { have vague } \\
\text { objectives and } \\
\text { goals } \\
\text { - Spread power } \\
\text { - Create } \\
\text { concepts of } \\
\text { complexity and } \\
\text { chaos }\end{array}$ & $\begin{array}{l}\text { Attitudes - what } \\
\text { good leaders are: } \\
\text { - Self-aware } \\
\text { - Flexible } \\
\text { - Open } \\
\text { - Honest } \\
\text { - Discrete } \\
\text { - Visible, outgoing } \\
\text { - Willing to be } \\
\text { wrong/accept } \\
\text { advice/support } \\
\text { - Sensitive to other } \\
\text { aspects }\end{array}$ \\
\hline $\begin{array}{l}\text { Inspire a shared } \\
\text { vision: } \\
\text { - Envision the } \\
\text { future by } \\
\text { imagining exciting } \\
\text { possibilities } \\
\text { - Enlist others in a } \\
\text { shared vision by } \\
\text { appealing to shared } \\
\text { aspirations }\end{array}$ & $\begin{array}{l}\text { - Build a } \\
\text { reciprocal } \\
\text { community and } \\
\text { shared } \\
\text { responsibiliti } \\
\text { es • Develop } \\
\text { a shared } \\
\text { vision • } \\
\text { Model trust } \\
\text { - Contact and } \\
\text { listen } \\
\text { to staff }\end{array}$ & $\begin{array}{l}\text { - Provide feedback } \\
\text { on performance } \\
\text { - Provide resources } \\
\text { for and adjust } \\
\text { workloads to } \\
\text { stimulate } \\
\text { scholarship and } \\
\text { research } \\
\text { - Make academic } \\
\text { appointments that } \\
\text { enhance the } \\
\text { department's } \\
\text { reputation }\end{array}$ & $\begin{array}{l}\text { Know yourself: } \\
\text { - Context } \\
\text { - Education } \\
\text { - Relationships } \\
\text { - Analyses } \\
\text { - Politics } \\
\text { - Solutions }\end{array}$ & $\begin{array}{l}\text { Social: } \\
\text { - Social identity } \\
\text { - Informal } \\
\text { - Networks } \\
\text { - Partnerships } \\
\text { - Alliances }\end{array}$ & $\begin{array}{l}\text { - Develop novel } \\
\text { solutions } \\
\text { - Use a diverse } \\
\text { cognitive lens to } \\
\text { handle } \\
\text { complexity }\end{array}$ & $\begin{array}{l}\text { Knowledge - what } \\
\text { good leaders } \\
\text { know: } \\
\text { - Knowledge of } \\
\text { university life } \\
\text { - Understand how the } \\
\text { university system } \\
\text { matters } \\
\text { - Understand } \\
\text { academic processes }\end{array}$ \\
\hline $\begin{array}{l}\text { Challenge the } \\
\text { process } \\
\text { - Search for } \\
\text { opportunities by } \\
\text { seeking creative } \\
\text { pathways to } \\
\text { transform, grow, and } \\
\text { improve } \\
\text { •Experiment and tak } \\
\text { risks by continually } \\
\text { recognizing small } \\
\text { successes and } \\
\text { learning from past }\end{array}$ & $\begin{array}{l}\text { Challenge the } \\
\text { process } \\
\text { - Search for } \\
\text { opportunities by } \\
\text { seeking creative } \\
\text { pathways to } \\
\text { transform, grow, } \\
\text { and improve } \\
\text { - Experiment and } \\
\text { take risks by } \\
\text { continually } \\
\text { recognizing } \\
\text { small successes } \\
\text { and learning } \\
\text { from past } \\
\text { Enable everyone }\end{array}$ & $\begin{array}{l}\text { - Consider } \\
\text { relationships } \\
\text { of trust, } \\
\text { warmth, and } \\
\text { mutual respect } \\
\text { - Create a } \\
\text { positive and } \\
\text { collegial work } \\
\text { atmosphere in } \\
\text { the } \\
\text { department }\end{array}$ & $\begin{array}{l}\text { Lead your } \\
\text { department: } \\
\text { - Identify key } \\
\text { aims and } \\
\text { capacities } \\
\text { - Examine } \\
\text { performance } \\
\text { • Review mission } \\
\text { and plan } \\
\text { - Examine } \\
\text { strategic } \\
\text { orientation } \\
\text { - Identify } \\
\text { objectives and } \\
\text { KPIs • Manage }\end{array}$ & $\begin{array}{l}\text { Structural \& } \\
\text { organizational } \\
\text { - Systems } \\
\text { - Processes } \\
\text { - Practices }\end{array}$ & $\begin{array}{l}\text { - Apply } \\
\text { outside } \\
\text { circumstance } \\
\text { s for } \\
\text { innovation } \\
\text { - Listen to } \\
\text { marginal } \\
\text { people } \\
\text { Gather } \\
\text { supplementar } \\
\text { y data as key } \\
\text { to making } \\
\text { effective and } \\
\text { ethical, } \\
\text { cognitively } \\
\text { complex } \\
\text { decisions }\end{array}$ & \\
\hline
\end{tabular}


leadership

- Shared your personal values with staff

- Community meetings and recognizing "small success" are helpful

- Find leverage points in an academic organization risk

\section{Encourage the}

heart:

- Recognize contributions by showing appreciation for personal excellence

- Celebrate the values and wins by keeping a spirit of community

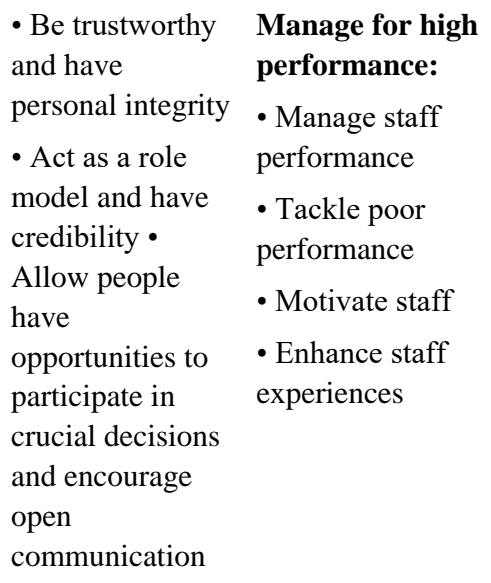

\begin{tabular}{|c|c|}
\hline $\begin{array}{l}\text { Developmental: } \\
\text { • Individual, group, } \\
\text { and organizational } \\
\text { development } \\
\text { - Integration with } \\
\text { organizational } \\
\text { systems } \\
\text { - Career pathway } \\
\text { - Changing needs } \\
\text { and priorities }\end{array}$ & $\begin{array}{l}\text { environment to } \\
\text { develop } \\
\text { strategies for } \\
\text { problems } \\
\text { • Leadership } \\
\text { processes } \\
\text { addressed } \\
\text { when they } \\
\text { involve the } \\
\text { pathway to } \\
\text { embrace } \\
\text { learning } \\
\text { - Establish a } \\
\text { balance } \\
\text { between } \\
\text { autonomy and } \\
\text { accountability } \\
\text { in the } \\
\text { leadership } \\
\text { process } \\
\text { • University } \\
\text { is a } \\
\text { semi-autono } \\
\text { mous system } \\
\text { that is } \\
\text { innately } \\
\text { pliable and } \\
\text { responds to } \\
\text { change }\end{array}$ \\
\hline
\end{tabular}

\subsection{The New Challenges for the Double First-Class Universities in China}

Hazelkorn (2011) explored the top HEIs and built the Emerging Global Model based on the characteristics identified. 1) mission extending beyond national boundaries; 2) incremental escalation of knowledge production; 3) transforming academic positions, outcomes, and achievement systems; 4) various sources of finance beyond government support and student contributions; 5) states facilitate the association between HE and the private sector; 6) world-wide employment; 7) increasingly complex organizational model with attributes of a loosely coupled system; and 8) global partnerships through networked nodes. Wu (2019) suggested that top universities might concentrate on these five attributes: academic staff, publication, student quality, academic reputation, and social contribution. 
Regarding China, Zhou (2016a) commented that the core aim of building "double firstclass" universities requires adjusting the relationship between teaching and research. To enable the development of universities with Chinese characteristics, leaders need to focus on instruction advancement, based on "double first-class" reform, design advanced discipline, reconstruct the concepts of professional education, build systems of training talents, and evaluate standards of international scholarship (Zhou, 2016b). In the same year, Ma (2016) indicated that the double-class objective requires universities to change from the traditional government-based to the comparative market-based. Undergraduate education plays a primary role in building double first-class (Zhong and Fang, 2016). In 2016, Vice President Ren of East China Normal University claimed that HE has the commitment for making the world better, while globalization is an important tool that universities should exploit to accomplish this mission. According to Ma's opinion, modern universities in China started late, and their institutional foundation is weak; they have to learn from western universities and high-quality colleges. With the rapid globalization in economics, HEs, and knowledges, double-class universities desire to learn from the systems of excellent universities (Ma, 2016).

Furthermore, Zhou (2016b) concluded three vital pillars of a university-constructing systems, management, and techniques. HEIs in China currently lack autonomy. The relationship between universities and government is the key to system reform. There are several kinds of relationships in college reform are challenging, for instance, the relationship of party and government, the relationship of scholarship and administration, the relationship of college setting and assessment of academics. In Pan's (2016) study, she manifested the key content and action plan for a double-class building is the top class disciplines.

\subsection{Sustainable Leadership Theories and Models}

This section contains several important theories and models of sustainable leadership in the education field. They are Seven Principles of Sustainable Leadership, Eight Factors of Sustainability, Framework for Strategic Sustainable Development, Honeybee Sustainable Leadership Practices, Importance and Need for Sustainable Leadership in Education, Ten Principles of Sustainable Leadership, Five Attributes of Sustainable Leaders and Five Leadership Challenges.

\subsubsection{Seven Principles of Sustainable Leadership}

Hargreaves and Fink (2003a) highlight seven principles of sustainable leadership as follows:

\section{Sustainable leadership assists and supports sustained learning}

Sustained learning, which alludes to learning worked, requires and sustains students' mental, social, and emotional engagement. It is not success outcomes but the learning behind them that matters most. Educational leaders are responsible for sustained learning (Hargreaves and Fink, 2003a). Lambert (2012) adds that deep learning is required, rather than a narrow focus on exams and superficially designed achievements.

\section{Sustainable leadership assures success over time}

Sustainable leadership is a dispensable challenge for education that hits and embraces a university multifaceted (Lambert, 2012). Sustainable enhancements do not change or disappear when the leader departs. Charming leaders may not accomplish sustainable development; instead, that transcends individual impact that relates the performances of leaders to their former leaders and new leaders (Hargreaves and Fink, 2003a).

\section{Sustainable leadership promotes the leadership in others}

To share leadership with others is a pathway for leaders to leave a continuing bequest, not just a top man or woman (Lambert, 2011, 2012; Hargreaves and Fink, 2003a). Leadership succession here is more than training a leader's successors: it entails dispensing leadership throughout the institution's professional community.

\section{Sustainable leadership enhances issues of social justice}

Sustainable leadership does not ask institutions collect the best students and teachers from around universities, nor flourish though the spending of other universities in the district (Lambert, 2011, 2012). Sustainable leadership calls for collaboration and is suitable for all universities and students. As an interdependent procedure, it is responsible that universities influence one another in relationships of reciprocal impact. On this matter, sustainable leadership is inseparably linked to social justice (Hargreaves and Fink, 2003a).

\section{Sustainable leadership sustains rather than exhausts resources}

Sustainable leaders use both internal and external motivations to attract and retain the best and most dynamic in the leadership pool. They also give opportunities for leaders to communicate, learn, and receive support from each other, along with coaching and mentoring successors (Hargreaves and Fink, 2003a). People learn from one another and 
create a climate of social inclusion (Lambert, 2011, 2012).

\section{Sustainable leadership develops diverse environment}

The presidents refine and build the environment to foster university vastly extensive and lasting enhancement. They stimulate people to be adaptive and blossom in their increasingly chaotic environment by learning from other diverse experiences (Hargreaves and Fink, 2003a).

\section{Sustainable leadership actively engages with the environment}

Creative institutions have missed a lot of their border as traditional universities. These universities are not just creating innovation. As the learning communities, indeed, they also involves confidently with its history, HEIs should be proud of the past and compose a new era (Lambert, 2011, 2012; Hargreaves and Fink, 2003a).

\subsubsection{Eight Factors of Sustainability}

Fullan (2004) summarized eight factors of sustainable leadership:

\section{Public service with ethical goals}

Fullan defined ethical goals as three pathways: (1) be responsible for raising the bar and closing the gap in students' academic achievements; (2) respect people without distain; and (3) lead on the improvement of the surrounding environment.

\section{Accountability for transforming situations at all levels}

Primarily, educational leaders must respond to the changing context. The remaining six factors involve providing people with new practices, capabilities, and acumens into what has and could be finished as the leaders.

\section{Skills-building by networks}

Lateral capacity alludes to networks and collaborates that is valuable for institution enhancement. Deep accountability leads to the realization that endure or skills-building is essential, which leads to direct skills-building with outside coaches at the district or other levels, that lateral skill-building with peers is a valuable learning method.

\section{New interdependent relationships involving both capacity-building and commitment}

Sustainable communities have to handle the internal leadership and external commitment. Leaders go to motivate employers to explore positive outputs via internal capacity-building.

\section{Deep learning}

Sustainable leadership needs ongoing improvement, adaption, and problem-solving. Complex and adaptive problems require deep learning.

\section{Accountability for both short-term and long-term outcomes}

Similar to most dimensions of sustainability, things that seems like they are interdependent. The truth is that government and institution have to display move in connection with benefits in the short and long term. Consequently, the system can promote long-term policy as well as short-term outcomes.

\section{Regular energizing}

Principle 1: Involvement demands four resources of energy: physical, emotional, psychological, and spiritual.

Principle 2: Energy competency reduces both with overspends and with underuse, so organizations must balance resource expenses with irregular resources revival.

Principle 3: As for capacity building, institutions have lost many of edges and train people in the same systemic way like elites do.

Principle 4: Managing energy with highly serious norms is crucial to full involvement and sustainable high behaviors.

\section{Continued leadership}

On the one hand, a system oriented toward sustainability must be driven by leadership at all levels. On the other hand, the primary job of principals is to appropriately address and concurrently satisfy the prior seven factors.

\subsubsection{Framework for Strategic Sustainable Development}

A framework for strategic sustainable development demonstrated by Dyer and Dyer (2017):

1. System: operation of the system - "society within the Biosphere" and the way of a university works. 
All the stakeholders, including leaders, faculty, staff, and students, contribute to the institution's sustainability. A university drives sustainability through various direct and indirect pathways. As sustainable labor increasing in society, the university strengthens thinking and intellectual frameworks to create sustainable systems and behaviors. Universities also produce many graduates and undertake research into social development issues.

\section{Success - fundamental principles for sustainability}

Social sustainability is the key for sustainable HE. In this system, students in all programs must learn systematic thinking skills and develop disciplines to address institutional sustainability.

\section{Strategy - based on the principles for achieving sustainability and a systematic plan}

Universities and colleges are often unprepared to transform. Educational leaders are usually pay insufficient attention to the interests of the faculty, custodians, benefactors and graduates, and other stakeholders of all functions.

\section{Action - definite performances that are appropriate for the principles}

Leaders and managers take action to achieve sustainability, for instance, through energy efficient using, renewable energy storage, innovative courses and curriculums, and building a research center on sustainable issues to meet the objectives.

\section{Tools - sets of theories, methods, and concepts that guide action and certify progress toward success}

Most universities and colleges do not have a specific vision and responsibility for a sustainable future. Various steps in research, operations, education, and community involvement might not be assessed with respect to their efforts to achieve that vision, nor their capacities to maintain or block other benevolent actions.

\subsubsection{Honeybee Sustainable Leadership Practices}

Kantabutra and Saratun (2013) identified six core practices of sustainable leadership:

\section{Aim at a long-term view}

Educational leaders must adopt a long-term perspective. Giving equal attention to both long-term and short-term perspectives is indispensable for all matters, but it is hard to attain when there is pressure to achieve short-term benefits at the expense of long-term benefits.

\section{People development}

By prioritizing specific skills, institutions develop staff skills through in-house and other training approaches that strongly support the continuing development of employees. Training is available to all employees, not just to managers or leaders.

\section{A strong institutional culture}

A university needs to construct a robust culture of shared values, which guides staff on how to act and fosters performance in line with expectations.

\section{Innovation}

Innovation is one of the primary resources of scientific procedures and economic expansion. Disruptive innovation concentrates on changes in product designs.

\section{Social environmental commitment}

Social environmental commitment is a grass roots of an organization. Educational organizations underpin commitment to social and environment issues, often because their leaders model the right actions, inducing morality behavior in others.

\section{Morality behavior}

Morality behavior is a pattern of risk management and means to enhance an institution's reputation. For schools that operate transparently, ethical methods can maintain the trust of stakeholders. Morality and ethical behavior could promote university sustainability in increasingly diversified ways.

\subsubsection{Importance and Need for Sustainable Leadership in Education}

Leaders should fellow items to develop sustainable leadership in schools (Cook, 2014):

1. Communicate and advance a broadly perceived university-vision;

2. Provide staff with continuing, job-embedded development of their professional capacities; 
3. Lead by example;

4. Promote and encourage leadership capability among teachers;

5. Foster and facilitate an inclusive organizational culture;

6. Invite and encourage collaboration in decision-making processes;

7. Promote two-way communication with staff;

8. Practice consensus building;

9. Model and strengthen the customs and skills of self-reflection;

10. Encourage strategical problem-solving skills in staff.

\subsubsection{Ten Principles of Sustainable Leadership}

Davies (2009) proposed ten principles of sustainable leadership:

1. Works to build and conserve sustained study;

2. Secures permanent success over time;

3. Sustains the leadership for other people;

4. Is social justice;

5. Focuses on developing instead of depleting resources;

6. Enhances the diversity and capability of settings;

7. Actively engages assert its environments;

8. Maintains awareness of conditions to ensure they remain healthy and do not start to decline;

9. Remembers the history and builds a new future;

10. Demonstrates patient by deferring pleasure, rather than finding quick outcomes.

\subsubsection{Five Attributes of Sustainable Leaders}

According to Goolamally and Ahmad (2014), a sustainable leader has the following five attributes:

1. Rightness: the quality or state of being morally good, justified, or acceptable;

2. Progressiveness: the ability to implement reform, adopt a strategy, and motivate others;

3. Inspiring: means to gain support and exercise influence;

4. Competence: specifically action-orientation competency and emotional or spiritual competency;

5. Self-efficacy: the belief in one's ability to do something successfully.

\subsubsection{Five Leadership Challenges (Crews, 2010)}

Crew (2010) put forward five leadership challenges as the strategies for implementing sustainability.

\section{Stakeholder engagement}

Sustainable leadership involves synthesizing the demands and benefits of all stakeholders. The associated capacities involve the ability of an institution to engage in a keeping conversation with each community of interest.

\section{Creating the culture}

A sustainable leader must acknowledge and understand shared values. Thus, sustainability could be a core value. Educational leaders need to regularly review the mission, vision, values, standards, and responsibilities concerning sustainability.

\section{Holistic thinking}

In this chaotic era, university leaders will distinguish and know the truth in which simple answers, quick adaptations, and magic bullets are rare. With the routes to success becoming increasingly problematic and puzzling, strategies are needed in which natural growth and creation for sustainability. The educational leaders are expected to collect data and conduct analysis to know the situation and encourage everyone around a vision for the future. 


\section{Organizational learning}

Organizational learning includes three pillars. The first is talent management, which combines sustainable development with human resources to select appropriate staff. The second is training and development, into which sustainability must be integrated. The third is leadership development, which calls for the development of sustainable leadership capacity at all levels.

\section{Measurement and reporting}

Sustainable leaders need to create an innovative and creative culture to explore appropriate strategies for implementing sustainability, and then choose an appropriate measurement and reporting system, grounded in what matters within the specific organizational culture.

\subsection{Sustainable Leadership Framework}

Lambert (2011) identifies a sustainable leadership framework for education colleges (Table 2). He developed the model based on the sustainable leadership models of Hargreaves and Fink (2003a), Fullan (2004), and Davies (2009).

Table 2. A sustainable leadership framework for higher education

\begin{tabular}{lll}
\hline Principle & Name & Summary \\
1 & $\begin{array}{l}\text { Develop employees' } \\
\text { abilities }\end{array}$ & $\begin{array}{l}\text { Offer opportunities for employees to build } \\
\text { their capabilities and experience leadership and management }\end{array}$ \\
2 & Strategic distribution & $\begin{array}{l}\text { Allow people at all levels of the organization to engage in } \\
\text { leadership practices, giving rise to sustainable development }\end{array}$ \\
3 & Consolidate & $\begin{array}{l}\text { Empower collaboration between staff to maintain learning meets } \\
\text { the customer needs }\end{array}$ \\
4 & $\begin{array}{l}\text { Create long-term } \\
\text { objectives from } \\
\text { short-term objectives } \\
\text { short-term goals enforced by funding agencies }\end{array}$ \\
Diversity & $\begin{array}{l}\text { Build a diverse learning community and ensure open and cohesive } \\
\text { institutions }\end{array}$ \\
5 & Preserve & $\begin{array}{l}\text { Honor and learn from the past to make a better future } \\
6\end{array}$
\end{tabular}

Table 3. Component Parts of the sustainable leadership model and theories for higher education institutions

\begin{tabular}{|c|c|c|c|c|c|c|c|}
\hline $\begin{array}{l}\text { Hargreaves } \\
\text { Fink (2003a) }\end{array}$ & I Fullan (2004) & $\begin{array}{l}\text { Dyer and Dyer } \\
(2017)\end{array}$ & $\begin{array}{l}\text { Kantabutra } \\
\text { and Saratun } \\
(\mathbf{2 0 1 3})\end{array}$ & Cook (2014) & Davies, (2009) & Crews (2010) & $\begin{array}{l}\text { Lambert } \\
\text { (2011) }\end{array}$ \\
\hline Learning & Deep learning & System thinking & $\begin{array}{l}\text { Long-term } \\
\text { view }\end{array}$ & $\begin{array}{l}\text { Build and } \\
\text { foster a } \\
\text { university } \\
\text { vision }\end{array}$ & $\begin{array}{l}\text { Sustainable } \\
\text { learning }\end{array}$ & $\begin{array}{l}\text { Stakeholders' } \\
\text { involvement }\end{array}$ & $\begin{array}{l}\text { Develop } \\
\text { staff } \\
\text { capacity }\end{array}$ \\
\hline Evaluation & Accountability & $\begin{array}{ll}\text { Develop an } \\
\text { action plan }\end{array}$ & Innovation & $\begin{array}{l}\text { Staff } \\
\text { development }\end{array}$ & $\begin{array}{l}\text { Conserve } \\
\text { resources }\end{array}$ & $\begin{array}{l}\text { Create a } \\
\text { culture }\end{array}$ & $\begin{array}{l}\text { Encourage } \\
\text { collaboration }\end{array}$ \\
\hline $\begin{array}{l}\text { Develop } \\
\text { leadership } \\
\text { at all levels }\end{array}$ & $\begin{array}{l}\text { Continued } \\
\text { leadership }\end{array}$ & $\begin{array}{l}\text { Develop } \\
\text { strategies for } \\
\text { transformation }\end{array}$ & $\begin{array}{l}\text { Build a } \\
\text { culture }\end{array}$ & Skills-building & $\begin{array}{l}\text { Develop } \\
\text { leadership } \\
\text { capacity }\end{array}$ & $\begin{array}{l}\text { Holistic } \\
\text { thinking }\end{array}$ & $\begin{array}{l}\text { Long-term } \\
\text { benefits }\end{array}$ \\
\hline
\end{tabular}




\begin{tabular}{|c|c|c|c|c|c|c|}
\hline Social justice & $\begin{array}{l}\text { Public servic } \\
\text { with ethics }\end{array}$ & $\begin{array}{l}\text { eUse various } \\
\text { tools }\end{array}$ & $\begin{array}{l}\text { Ethical } \\
\text { behavior }\end{array}$ & $\begin{array}{l}\text { Enhance } \\
\text { inclusive } \\
\text { culture }\end{array}$ & Social justice & $\begin{array}{l}\text { OrganizationalDiversity } \\
\text { learning }\end{array}$ \\
\hline $\begin{array}{l}\text { Preserve } \\
\text { resources }\end{array}$ & $\begin{array}{l}\text { Regular } \\
\text { energizing }\end{array}$ & Skills-building & $\begin{array}{l}\text { Staff } \\
\text { development }\end{array}$ & $\begin{array}{l}\text { Develop staff } \\
\text { leadership } \\
\text { capacity }\end{array}$ & Diversity & $\begin{array}{l}\text { Measurement Preserve } \\
\text { and reporting resources }\end{array}$ \\
\hline Diversity & $\begin{array}{l}\text { Interdependent } \\
\text { relationships }\end{array}$ & & & $\begin{array}{l}\text { Leaders as } \\
\text { models with } \\
\text { self-reflection }\end{array}$ & Awareness & \\
\hline \multirow[t]{2}{*}{ Innovation } & Skills-building & & & $\begin{array}{l}\text { Two-way } \\
\text { communication }\end{array}$ & Create a future & \\
\hline & & & & & $\begin{array}{l}\text { Long-term } \\
\text { perspective }\end{array}$ & \\
\hline
\end{tabular}

\section{Findings}

The current challenges of double first-class universities in China have be determined. Under this situation, according to two eras of literatures on effective leadership and sustainable leadership in higher education, the author will develop a model of sustainable leadership for leaders in double first-class universities in China.

The author summarized component parts of the sustainable leadership model and theories for HEIs (Table 3), and stated a proposed framework of sustainable leadership for higher education (Table 4). Deep and continuing learning is the first component in a proposed framework of sustainable leadership for HE. Graduates develop skills in research, problem-solving, critical thinking, and knowledge management (Weigel, 2001). Innovation and creativity are commonly regarded as crucial capacities for boosting organizational keeping development (DiLiello and Houghton, 2006).

Sustainable leaders emphasize innovative and creative ability in systems, instruction, and academics. Ethics is centered on the requirements rooted in education, especially correlated to student outcomes (Peters, 2015). Ethical public service enables people to feel respect and ownership in the HE community. Collaboration is another challenge for sustainable university leaders. Ronfeldt et al. (2015) conducted a two-year study of teacher collaboration. They found that building a Professional Leaning Community (PLC) for faculties is a notable method for improving collaboration. Student show higher outputs on campuses and teachers have higher intention on collaboration in collaborative environment. University presidents provide a leadership program, training, or practices for every level in HE. Not only teachers and managers but also students and other staff demand support to develop their leadership skills, regardless of whether their roles are positional. Preservation is an essential element for the sustainable development of universities.

Hargreaves and Fink (2003b) argued that sustainable leadership ensures success over time. HE leaders should always make decisions with a long-term view and consider both current and future benefits. Iverson's (2007) findings suggest that well-aimed efforts to build more inclusive institutions might unintentionally enhance inclusive and equitable practices. To promote faculty professional development, universities provide training programs, mentorship, and integrate ICT and other effective pathways to teachers (Yue, 2019). 
Table 4. A proposed framework of sustainable leadership for higher education

\begin{tabular}{|c|c|c|}
\hline Attributes & Name & Description \\
\hline 1 & Deep and continuing learning & $\begin{array}{l}\text { Ensure learning at every level and build a } \\
\text { professional learning community }\end{array}$ \\
\hline 2 & Innovation & $\begin{array}{l}\text { Innovative and creative ability in systems, } \\
\text { instruction, and academics }\end{array}$ \\
\hline 3 & Ethics & $\begin{array}{l}\text { Ethical public service, emphasizing ethics and } \\
\text { morality }\end{array}$ \\
\hline 4 & Collaboration & Facilitate staff collaboration \\
\hline 5 & Build a university vision & $\begin{array}{l}\text { President sets a vision and high expectations for } \\
\text { the university }\end{array}$ \\
\hline 6 & Develop leadership capacities at all levels & $\begin{array}{l}\text { Provide leadership programs, training, or } \\
\text { practices for managers, teachers, and students }\end{array}$ \\
\hline 7 & Preservation & $\begin{array}{l}\text { Use both physical and human resources } \\
\text { effectively, without depletion }\end{array}$ \\
\hline 8 & Measurement and reporting & $\begin{array}{l}\text { Regularly evaluate operations and performance, } \\
\text { and provide a report to review }\end{array}$ \\
\hline 9 & Long-term perspective & $\begin{array}{l}\text { Make decisions based on a long-term view and } \\
\text { leverage current and future benefits }\end{array}$ \\
\hline 10 & Diversity & $\begin{array}{l}\text { Allow and respect individual and cultural } \\
\text { differences and encourage common purpose }\end{array}$ \\
\hline 11 & $\begin{array}{l}\text { Staff development and } \\
\text { skills-building }\end{array}$ & Focus on developing personal professional skills \\
\hline
\end{tabular}

\section{Implications}

Drawing on prior findings on effective leadership in HE, and sustainable leadership in HE, and challenges in Chinese HE, the author developed a model for sustainable leadership for double first-class universities in China (see Figure 2). Educational leaders of double first-class universities should concentrate on the five dimensions of sustainable leadership for leading the whole organization: Self, System, Function, People, and Environment. The "hub" of this model is LEAD. LEAD is the center of the model that everything undertaken by leading.

Reichard and Johnson (2011) highlighted five elements of leader self-development: 1) universal intelligence; 2) achievement orientation (need for achievement, profound locus of control, and energy); 3) mastery striving (self-efficacy, painstakingness, openness to new experience, study objectives, intellectual maturity, metacognition); 4) job-based increase (job experience, reflection and feedback) and; 5) work related (work motivation, task engagement, organizational responsibility). They found mastery orientation, job-based increase, and work related that all refer to self-development, both fixed and uncertain personal characteristics. Hence, in this model (Figure 2), Self involves the leader's own attitudes, abilities, skills, behaviors, and values. 


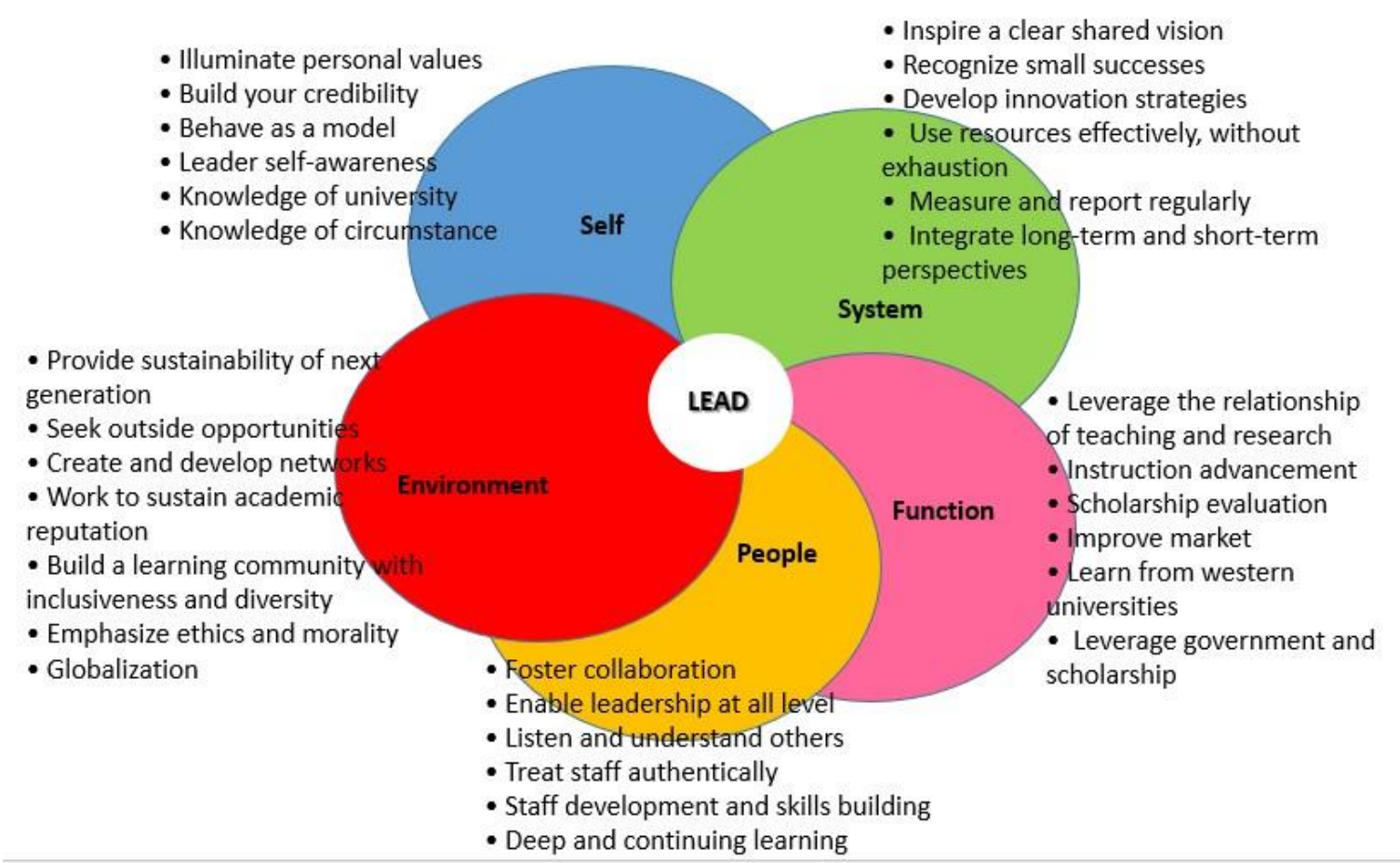

Figure 2. A model of sustainable leadership for double first-class universities in China

The System encompasses institution culture, research, strategy, policies, and capacity (Hopkins et al., 2013). In the context on which this paper focuses, sustainable leadership entails vision, innovation strategies, sustainability, evaluation, and integral benefits. Regarding Function, HE leaders need to leverage research and education. Scholars believe, the key to success in university, that research connects teaching. Definitely, there is a deep relationship between education and research (Marsh and Hattie, 2002). People The salient point of enhancing educational institutions is promoting teacher quality and the caliber of student learning (Opfer and Pedder, 2011), through teacher professional development, skills-building, and peer collaboration. The Environment dimension reminds educators to develop networks, enhance both internal and external reputation, and emphasize morality and ethics.

\section{Conclusion and Future Research}

This study reviewed and analyzed significant theories and research findings on effective leadership in HE, sustainable leadership in HE, and the challenges facing China's double first-class universities. The conceptual frameworks of effective leadership in HE and sustainable leadership in HE are provided for scholars. This paper's theoretical framework is only directly relevant to sustainable leadership for double first-class universities in China. It has not been tested through any quantitative or qualitative data. Future research will use quantitative methods to validate the model.

\section{Acknowledgment}

The authors acknowledge the financial support through Shaanxi Normal University High-level Talents Research Startup Project: "Research and Application Demonstration of Key Technologies for Monitoring and Evaluation of Chinese Universities" (1110011175).

Data sharing not applicable to this article as no datasets were generated or analysed during the current study.

\section{References}

Ameijde, J. D. J. V., Nelson, P. C., Billsberry, J., \& Meurs, N. V. (2009). Improving leadership in higher education institutions: a distributed perspective. Higher Education, 58, 763-779. https://doi.org/10.1007/s10734-009-9224-y

Astin, A.W., \& Astin, H. S. (2000). Leadership Reconsidered: Engaging Higher Education in Social Change. Michigan: W. K. Kellogg Foundation.

Avery, G. C., \& Bergsteiner, H. (2011). Sustainable leadership practices for enhancing business resilience and performance. Strategy \& Leadership, 39, 5-15. https://doi.org/10.1108/10878571111128766 
Black, S. A. (2015). Qualities of Effective Leadership in Higher Education. Open Journal of Leadership, 4, 54-66. https://doi.org/10.4236/oj1.2015.42006

Bolden, R., Petrov, G., \& Gosling, J. (2007). Tensions in higher education leadership: towards a multi-level model of leadership practice. Higher Education Quarterly, Vol. 29, 358-376. https://doi.org/10.1111/j.1468-2273.2008.00398.x

Bolden, R., Petrov, G., \& Gosling, J. (2013). Distributed leadership in higher education: rhetoric and reality. Educational Management, Administration and Leadership. ISSN 1472-2939

Bryman, A. (2007). Effective leadership in higher education: a literature review. Studies in Higher Education, 32, 693-710. https://doi.org/10.1080/03075070701685114

Clarke, S., \& Stevens, E. (2009). Sustainable leadership in small rural universities: selected Australian vignettes. $J$. Educ. Change, 10, 277-293. https://doi.org/10.1007/s10833-008-9076-8

Cook, J. W. (2014). Sustainable school leadership: the teachers' perspective. International Journal of Educational Leadership Preparation, 9. ISSN: ISSN-2155-9635.

Crews, D. E. (2010). Strategies for implementing sustainability: five leadership practices. Advanced Management Journal.

Davies, B. (2009). The Essentials of University Leadership: Sustainable Leadership. London: Sage. https://doi.org/10.4135/9781446288290

Delanty, G. (2001). Challenging Knowledge: The University in the Knowledge Society. https://doi.org/10.1177/1350508401082002

Buckingham: The Society for Research into Higher Education \& Open University Press.

DiLiello, T. C., \& Houghton, J. D. (2006). Maximizing organizational leadership capacity for the future: toward a model of self-leadership, innovation and creativity. Journal of Managerial Psychology, 21, 319-337. https://doi.org/10.1108/02683940610663114

Dyer, G., \& Dyer, M. (2017). Strategic leadership for sustainability by higher education: the American College \& University Presidents' Climate Commitment. Journal of Cleaner Production, 140, 111-116. https://doi.org/10.1016/j.jclepro.2015.08.077

Fullan, M. (2004). Leadership and Sustainability. System Leaders in Action. London: SAGE.

Goolamally, N., \& Ahmad, J. (2014). Attributes of school leaders towards achieving sustainable leadership: a factor analysis. Journal of Education and Learning, 3. https://doi.org/10.1016/j.jclepro.2015.08.077

Hargreaves, A. (2007). Sustainable leadership and development in education: creating the future, conserving the past. European Journal of Education, 42. https://doi.org/10.1111/j.1465-3435.2007.00294.x

Hargreaves, A., \& Fink, D. (2003a). The Seven Principles of Sustainable Leadership.

Hargreaves, A., \& Fink, D. (2003b). Sustaining leadership. Phi Delta Kappan, 84, 693-700. https://doi.org/10.1177/003172170308400910

Hargreaves, A., \& Fink, D. (2008). Energizing leadership for sustainability.

Hazelkorn, E. (2011). Rankings and the Reshaping of Higher Education: The Battle for World-Class Excellence. New York: Palgrave Macmillan. https://doi.org/10.1057/9780230306394

Hopkins, D., Stringfield, S., Harris, A., Stoll, L., \& Mackay, T. (2013). University and System Improvement: A Narrative State of the Art Review. https://doi.org/10.1080/09243453.2014.885452

Iverson, S. V. (2007). Camouflaging power and privilege: a critical race analysis of university diversity policies. Educational Administration Quarterly, 43, 586-611. https://doi.org/10.1177/0013161X07307794

Jones, S., Lefoe, G., Harvey, M., \& Ryland, K. (2012). Distributed leadership: a collaborative framework for academics, executives and professionals in higher education. Journal of Higher Education Policy and Management, 34, 67-78. https://doi.org/10.1080/1360080X.2012.642334

Kantabutra, S., \& Saratun, M. (2013). Sustainable leadership: honeybee practices at Thailand's oldest university. International Journal of Educational Management, 27, 356-376. https://doi.org/10.1108/09513541311316304 
Kezar, A. J. (2008). Rethinking the "L" Word in Higher Education: The Revolution of Research on Leadership. John Wiley \& Sons.

Kouzes, J. M., \& Posner, B. Z. (2006). Student Leadership Practices Inventory. San Francisco, CA: Jossey-Bass.

Lambert, S. (2011). Sustainable leadership and the implication for the general further education college sector. Journal of Further and Higher Education, 35, 131-148. https://doi.org/10.1080/0309877X.2010.540319

Lambert, S. (2012). The perception and implementation of sustainable leadership strategies in further education colleges. Journal of Leadership Education, 11. https://doi.org/10.12806/V11/I2/RF6

Ma, Y. Q. (2016). Double first-class building and university development. Journal of National Academy of Educational Administration, 9, 9-15.

Marsh, H. W., \& Hattie, W. (2002). The relation between research productivity and teaching effectiveness: complementary, antagonistic, or independent constructs? The Journal of Higher Education, 73. https://doi.org/10.1353/jhe.2002.0047

McCaffery, P. (2019). The Higher Education Manager's Handbook: Effective Leadership and Management in Universities and Colleges (Third edition). London: Routledge. https://doi.org/10.4324/9781351249744

Morsing, M., \& Oswald, D. (2009). Sustainable leadership: management control systems and organizational culture in Novo Nordisk A/S. Corporate Governance: The International Journal of Business in Society, 9, 83-99. https://doi.org/10.1108/14720700910936083

Opfer, V. D., \& Pedder, D. (2011). Conceptualizing teacher professional learning. Review of Educational Research, 81, 376-407. https://doi.org/10.3102/0034654311413609

Pan, J. (2016). Content and action outline of double first-class building. Jiangsu Higher Education, 5, 24-27.

Peters, R. S. (2015). Ethics and Education. London: Routledge. https://doi.org/10.4324/9781315712383

Ren, Y. Q. (2016). The future development of globalization of higher education under the strategy of double first-class building. China Higher Education, 5, 15-17.

Reichard, R. J., \& Johnson, S. K. (2011). Leader self-development as organizational strategy. The Leadership Quarterly, 22, 33-42. https://doi.org/10.1016/j.leaqua.2010.12.005

Ronfeldt, M., Farmer, S. O., McQueen, K., \& Grissom, J. A. (2015). Teacher collaboration in instructional teams and student achievement. American Educational Research Journal. https://doi.org/10.3102/0002831215585562

Spendlove, M. (2007). Competencies for effective leadership in higher education. International Journal of Educational Management, 21, 407-417. https://doi.org/10.1108/09513540710760183

Weigel, V. B. (2001). Deep Learning for a Digital Age: Technology's Untapped Potential to Enrich Higher Education. San Francisco: Wiley.

Weenen, H. V. (2000). Towards a vision of a sustainable university. International Journal of Sustainability in Higher Education, 1, 20-34. https://doi.org/10.1108/1467630010307075

Wu, J. X. (2019). Policy direction, core values and the way of building for world first class disciplinary. China Higher Education Research, 2, 28-33.

Zhao, Y., Liu, F., \& Zhao, T. T. (2019). From world top university building to double first class building: based on the review of research history in CNKI. Journal of National Academy of Education Administration, 3, 25-32.

Zhong, B. L., and Fang, F. (2016). First-class undergraduate education is importance of double first-class building. China's University Teaching, 4, 4-16.

Zhou, G. L. (2016a). On academic breakthrough in the construction of double worldclass: on the integrative construction of discipline, specialty and course in university. Educational Research, 5, 72-76.

Zhou, G. L. (2016b). Double world-class building: system, management and technology. University Education Science, $4,5-14$.

\section{Copyrights}

Copyright for this article is retained by the author(s), with first publication rights granted to the journal.

This is an open-access article distributed under the terms and conditions of the Creative Commons Attribution license (http://creativecommons.org/licenses/by/4.0/). 